\title{
Growth Hormone Responses to
}

\section{Thyroid Hormone in the Neonatal Rat}

\author{
RESISTANCE AND ANAMNESTIC RESPONSE
}

\author{
Hisao Seo, Caryn Wunderlich, Gilbert Vassart, and Samuel Refetoff, \\ Thyroid Study Unit, University of Chicago, Chicago, Illinois 60637
}

\begin{abstract}
A B S T RAC T Differences in the growth hormone $(\mathrm{GH})$ responses to primary and to secondary stimulation with triiodothyronine (T3) were studied in rats deprived of thyroid hormone from birth. Neonatal hypothyroidism was induced in pups by feeding pregnant rats an iodine-deficient, propylthiouracil-containing diet. T3 stimulation was carried out in pups by subcutaneous injection of a single dose of $50 \mu \mathrm{g} \mathrm{T} 3 / 100 \mathrm{~g}$ body wt. Pituitary GH content, rate of GH synthesis in vitro, and GH messenger (m)RNA activity in a cellfree translation system were measured.
\end{abstract}

No significant differences in body weight and in pituitary GH content were observed between hypothyroid and normal pups at ages 1,3 , and $6 \mathrm{~d}$. 10- and 28-d-old hypothyroid pups showed a significant arrest of growth, decreased pituitary GH content, and development of $\mathrm{GH}$ responsiveness to $\mathrm{T} 3$. In contrast, serum thyroxine concentration in hypothyroid pups was $<0.15 \mu \mathrm{g} / \mathrm{dl}$, significantly lower than normal at all ages.

GH synthesis and GH mRNA activity studied in pituitaries of 28-d-old rats were expressed as percent total protein synthesis and percent mRNA activity, respectively. GH synthesis and mRNA activity were 3.0 and $2.6 \%$ in hypothyroid rats, 3.3 and $2.9 \%$ in hypothyroid rats given a single T3 injection $14 \mathrm{~d}$ earlier (T3-withdrawn rats), and 26.8 and $27.1 \%$ in normal rats. Administration of $\mathrm{T} 3$ to hypothyroid rats induced an increase in GH synthesis and GH mRNA activity, reaching 5.8 and $5.6 \% 12 \mathrm{~h}$ after primary stimulation and 12.2 and $16.1 \% 12 \mathrm{~h}$ after secondary stimulation. The response rates were linear but 2.5 -fold more rapid after secondary stimulation. The latter response was similar to that observed after T3 stimulation of rats

Dr. Vassart is a Chercheur Qualifié au Fonds National de la Recherche Scientifique at the Institut de Recherche Interdisciplinaire, Free University of Brussels, Belgium.

Received for publication 23 June 1980 and in revised form 15 October 1980. rendered hypothyroid during adulthood. The responses of GH synthesis and mRNA activity were concordant after both primary and secondary T3 stimulation. A twofold increase in both parameters was observed as early as $2 \mathrm{~h}$ after T3 injection.

Four conclusions can be drawn from these experiments. First, during neonatal life, GH accumulation in rat pituitaries is independent of thyroid hormone and is insensitive to T3. Second, GH dependence on and sensitivity to thyroid hormone is acquired between the 6th and 10th d of neonatal life. Third, secondary T3 stimulation produces an anamnestic response manifested by an increased rate of GH synthesis and mRNA activity. Fourth, primary T3 stimulation is not associated with a lag in the endogenous translation of the newly accumulated GH mRNA.

\section{INTRODUCTION}

We have previously shown differences in the rate and time of prolactin (PRL) ${ }^{1}$ response to estrogen when given to male rats previously unexposed to the hormone (primary stimulation) and when it was given for a second time after a period of withdrawal (secondary stimulation) (1). Differences were of dual nature. First, the rate of cytoplasmic PRL messenger (m)RNA accumulation was much slower after primary stimulation, and second, a lag period between the accumulation of PRL mRNA and stimulation of endogenous synthesis of PRL was observed. A similar increase in the rate of accumulation of egg protein mRNA in the cytoplasm of oviduct and liver of birds and of amphibians previously exposed to estrogen has been observed by a number of investigators (2-7). After both primary and secondary stimulation, however, synthesis of the

\footnotetext{
${ }^{1}$ Abbreviations used in this paper: GH, growth hormone; $\mathrm{m}$, messenger; PRL, prolactin; T3, triiodothyronine; T4, thyroxine.
} 
specific protein proceeded in parallel with the level of its mRNA. A lag before the newly accumulated vitellogenin mRNA became endogenously translated has been noted during primary stimulation of the male Xenopus with estrogen (8).

In a preliminary experiment on the correlation between thyroid hormone-induced growth hormone $(\mathrm{GH})$ synthesis and mRNA activity, we failed to observe such a lag (9). Because of the possibility that even prolonged thyroid hormone deprivation may not abolish the anamnestic response to thyroid hormone, a neonatal rat model was developed to determine whether synthesis lag is a common phenomenon after primary exposure to hormones acting at the gene level. Results from experiments reported here show that the neonatal rat is unresponsive to thyroid hormone. Furthermore, the slower induction of GH mRNA after a primary exposure to thyroid hormone is not accompanied by a lag in the endogenous translation of the accumulated specific mRNA.

\section{METHODS}

Mature male and female rats of the $\mathrm{C} / \mathrm{D}$ strain, weighing 200-250 g, were obtained from Charles River Breeding Laboratories, Inc., Wilmington, Mass. They were kept in a temperature-controlled $\left(19-20^{\circ} \mathrm{C}\right)$ and artificially illuminated (light from 0700 until $1900 \mathrm{~h}$ ) room. In all experiments, rats were killed between 1230 and $1400 \mathrm{~h}$. Triiodothyronine (T3) treatment, described below, was planned accordingly.

Preparation of adult hypothyroid rats. Male rats were surgically thyroidectomized and placed on low iodide diet (Teklad Co., Madison, Wis.) and 0.9\% calcium chloride in the drinking water. 1 mo later, each rat was injected intraperitoneally with $80 \mu \mathrm{Ci}$ of $\mathrm{Na}^{125} \mathrm{I}$ (Industrial Nuclear Co., St. Louis, Mo.). Normal controls were fed regular Purina laboratory chow (Ralston Purina Co., St. Louis, Mo.) and given tap water. Access to food and water was unrestricted and animals were housed 5-6/cage. Experiments were carried out 2 mo later as described below.

Preparation of neonatal hypothyroid rats. After a 1-wk period of acclimatization to the animal quarters, female rats, housed 5/cage, were exposed for $2 \mathrm{~d}$ to three male rats. $15 \mathrm{~d}$ later, a group of impregnated rats was started on low iodine diet containing $0.15 \%$ propylthiouracil (Teklad Co.), while another was continued on a regular diet, both provided ad lib. These diets were maintained after delivery and throughout the entire period of the experiments. $2 \mathrm{~d}$ before the expected day of delivery, each female was placed in an individual cage and visited every $6 \mathrm{~h}$. Pups were weighed upon delivery and at various intervals thereafter. Pups were removed randomly from different litters at $1,3,6$, and $10 \mathrm{~d}$ for the study of pituitary GH content as described below. On the 5 th $d$ after delivery, the number of pups per mother was readjusted to eight. GH synthesis and GH mRNA activity in response to primary and secondary treatment with $\mathrm{T} 3$ was studied in 28-d-old rats as described below.

Protocol for the study of the evolution of the pituitary GH content in neonatal rats. Three groups of three to four pups each were studied at ages $1,3,6,10$, and $28 \mathrm{~d}:(a)$ normal pups; $(b)$ hypothyroid pups born from propylthiouraciltreated mothers; and (c) hypothyroid pups $24 \mathrm{~h}$ after the subcutaneous injection of $50 \mu \mathrm{g} \mathrm{T} 3 / 100 \mathrm{~g}$ body wt. Pups were killed under light ether anesthesia by exsanguination into the chest cavity after heparinization and closed-chest needle injury of the heart. Blood accumulated in the diaphragmatic recess was collected with a Pasteur pipette, and the plasma separated by centrifugation. This technique allowed collection of from 0.2 to $0.4 \mathrm{ml}$ of plasma in 1-d-old pups and from 0.3 to $0.6 \mathrm{ml}$ of plasma in 10-d-old pups. 28-d-old rats were bled by direct cardiac puncture. Plasma was stored at $-20^{\circ} \mathrm{C}$ until assayed for thyroxine (T4) and T3 concentrations.

After exsanguination, the pituitary was immediately exposed through an anterior craniotomy approach, and the posterior lobe was removed and discarded. The anterior pituitary was resected in toto, weighed, homogenized in $0.5 \mathrm{ml}$ of phosphate-buffered saline $(20 \mathrm{mM}$ sodium phosphate, 140 $\mathrm{mM}$ sodium chloride, $\mathrm{pH} 7.4$ ), and stored at $-20^{\circ} \mathrm{C}$ until assayed for GH content.

Protocol for the study of T3-induced GH synthesis and GH mRNA activity in adult hypothyroid rats. 24 hypothyroid male rats, prepared as described above, were divided into four groups of 6 rats each. One group was untreated and the other three received a single intraperitoneal injection of $50 \mu \mathrm{g} \mathrm{T} 3 / 100 \mathrm{~g}$ body wt, 2,6 , and $12 \mathrm{~h}$ before the termination of the experiment. In addition, 12 normal age-matched male rats were divided into two groups of 6 . One group was not treated and the other received T3 as above, $12 \mathrm{~h}$ before termination of the experiment. Treatment was staggered so that all rats were killed together by exsanguination through cardiac puncture under light ether anesthesia. Pituitaries were immediately dissected as described above, and GH synthesis and mRNA activity determined as outlined below. Serum was stored at $-20^{\circ} \mathrm{C}$ for measurement of T4 and T3 concentrations. On the day of the experiment, mean $\pm S D$ weights of hypothyroid and normal rats were 190 \pm 17 and $419 \pm 36$ g, respectively.

Protocol for the study of GH synthesis and GH mRNA activity in response to primary and secondary $T 3$ stimulation. Neonatal hypothyroid rats were prepared as described above. All rats were 28-d-old at termination of the experiment. Seven groups of six rats each were studied: $(a)$ untreated hypothyroid; $(b, c) 4$ and $12 \mathrm{~h}$ after primary T3 stimulation given at 28 days of age; $(d, e) 4$ and $12 \mathrm{~h}$ after secondary T3 stimulation given at age $28 \mathrm{~d}$, after a primary T3 stimulation at $14 \mathrm{~d} ;(f)$ withdrawn animals $28 \mathrm{~d}$ old, given a single T3 injection at age $14 \mathrm{~d}$; and $(g)$ normal controls. In all instances, T3 was given as a single subcutaneous dose of $50 \mu \mathrm{g} / 100 \mathrm{~g}$ body wt. Rats were killed, and the pituitaries were dissected out as described above.

Determination of pituitary GH synthesis. GH synthesis rate was assessed from measurement of newly synthesized hormone by pulse labeling in vitro as described in greater detail elsewhere (9). Briefly, pituitaries from adult rats were divided into eight fragments and those from pups into four fragments. Incubation was carried out in duplicate flasks containing three fragments from individual rats from the same group. After $1 \mathrm{~h}$ preincubation, protein synthesis was carried out at $37^{\circ} \mathrm{C}$ in the presence of $50 \mu \mathrm{Ci}\left[{ }^{3} \mathrm{H}\right]$ leucine/ml of glucose-supplemented Krebs-Ringer's lactate $\left(\left[{ }^{3} \mathrm{H}\right]\right.$ leucine from Amersham Corp., Arlington Heights, Ill.). The viability of the tissue and uninterrupted synthetic function under the in vitro conditions were previously demonstrated (9). Total protein synthesis was measured by trichloroacetic acid precipitation and $\mathrm{GH}$ synthesis by specific immunoprecipitation (9) of $\left[{ }^{3} \mathrm{H}\right]$ leucine. The recovery of $\mathrm{GH}$ in the immunoprecipitates was determined in each sample by coprecipitation of an added ${ }^{125}$ I-labeled GH tracer. Analysis of samples from each experiment was carried out in the same assay. Results are reported in terms of mean GH synthesized in duplicate determinations containing pituitary fragments from 
the six rats in each group and expressed as percent total protein synthesis.

Determination of pituitary GH mRNA activity. Pituitary tissue from each group of six animals not used for the determination of GH synthesis (3/4 of each gland from neonatal and $7 / 8$ of each gland from adult rats) was pooled and immediately frozen in liquid nitrogen. RNA was extracted with phenol-chloroform as previously described (9). Total mRNA and GH mRNA activities were measured using a micrococcal nuclease-treated, reticulocyte lysate cell-free translation system (10) under the conditions previously described in detail (9). All reactions were carried out simultaneously. Care was taken to use RNA concentrations in the range where the response of the cell-free translation system was linear with respect to RNA input $(80 \mu \mathrm{g} / \mathrm{ml})$. Results are reported in terms of mean GH mRNA activity in duplicate determinations and expressed as percent total mRNA activity.

Radioimmunologic techniques. Plasma T4 concentration was measured by a modification of a competitive proteinbinding assay (11) with a sensitivity of $0.10 \mu \mathrm{g}$ thyroxine/dl and a coefficient of variation of $5.9 \%$. Plasma T3 concentration was measured by a double-antibody radioimmunoassay (12) with a sensitivity of $10 \mathrm{ng} / \mathrm{dl}$ and a coefficient of variation of $7.0 \%$. GH content in pituitaries was measured by a doubleantibody radioimmunoassay (13) with a sensitivity of $10 \mathrm{ng} / \mathrm{ml}$ and a coefficient of variation of $5.0 \%$. Before analysis, the frozen pituitary homogenate, prepared as described above, was sonicated and centrifuged at $3,000 \mathrm{~g}$ for $10 \mathrm{~min}$. Several dilutions of the supernate were prepared in order to make use of the most sensitive and most accurate portion of the standard curve.

\section{RESULTS}

Table I shows the evolution of body weight, serum T4 and T3 concentrations, and pituitary GH content in hypothyroid and in normal rats from ages 1-28 d. There was no significant difference in the birth weight between hypothyroid and normal rats. Weights ranged from 4.7 to $7.2 \mathrm{~g}$ and from 4.9 to $6.7 \mathrm{~g}$, respectively. An inverse correlation was noted between the birth weight and the number of pups per litter. At the extremes, the mean \pm SD weight in litters of 5 pups was $6.9 \pm 0.2 \mathrm{~g} / \mathrm{pup}$, and in litters of $11-14 \mathrm{pups}, 5.2 \pm 0.1$ g/pup, irrespective of treatment. Significant arrest in growth of hypothyroid pups was first noted at $10 \mathrm{~d}$. The mean body weight of normal pups was $49.7 \%$ higher than that of hypothyroid pups, and further increased to the value of $164 \%$ in 28 -d-old pups. In contrast, serum $\mathrm{T} 4$ concentration was significantly lower in 1-d-old hypothyroid pups, $0.13 \pm 0.06 \mathrm{com}$ pared with $0.43 \pm 0.06 \mu \mathrm{g} / \mathrm{dl}$ in normal pups. Serum T4 concentration remained low in the hypothyroid pups throughout the entire period of observation, whereas it rose gradually in normal pups, reaching a value of $4.3 \pm 0.3 \mu \mathrm{g} / \mathrm{dl}$ at $28 \mathrm{~d}$. Serum T3 concentration was $<10 \mathrm{ng} / \mathrm{dl}$ in both normal and hypothyroid pups at 1 and $3 \mathrm{~d}$. At $6 \mathrm{~d}$, mean serum T3 level in the normal

TABLE I

Evolution of Body Weight, Serum $T_{4}$ and $T_{3}$, and Pituitary GH in the Neonatal Hypothyroid Rat and Effect of $T_{3}$

\begin{tabular}{|c|c|c|c|c|c|c|c|c|c|c|c|}
\hline \multirow[b]{2}{*}{ Age } & & \multicolumn{3}{|c|}{ Body weight } & \multicolumn{2}{|c|}{ Serum $\mathrm{T} 4$} & \multicolumn{2}{|c|}{ Serum $\mathrm{T}^{*}$} & \multicolumn{3}{|c|}{ Pituitary GH content } \\
\hline & & $\mathbf{N}$ & H & $N+T 3$ & $\mathbf{N}$ & H & $\mathrm{N}$ & H & $\mathbf{N}$ & $\mathbf{N}$ & $\mathrm{H}+\mathrm{T} 3$ \\
\hline$d$ & & \multicolumn{3}{|c|}{$g$} & \multicolumn{2}{|c|}{$\mu g / d l$} & \multicolumn{2}{|c|}{$n g / d l$} & \multicolumn{3}{|c|}{$\mu g$} \\
\hline 1 & $\begin{array}{l}\text { Mean } \\
\text { SD } \\
P\end{array}$ & $\begin{array}{l}5.7 \\
0.2\end{array}$ & $\begin{array}{r}5.5 \\
0.4 \\
S\end{array}$ & - & $\begin{array}{r}0.43 \\
0.06 \\
<\end{array}$ & $\begin{array}{l}0.13 \\
0.06 \\
005\end{array}$ & $<10$ & $<10$ & $\begin{array}{l}4.3 \\
0.08 \\
N\end{array}$ & $\begin{array}{l}5.4 \\
1.9\end{array}$ & - \\
\hline 3 & $\begin{array}{l}\text { Mean } \\
\text { SD } \\
P\end{array}$ & $\begin{array}{l}6.1 \\
0.7\end{array}$ & $\begin{array}{r}6.3 \\
1.0 \\
5\end{array}$ & $\begin{array}{r}5.3 \\
0.6 \\
S\end{array}$ & $\begin{array}{r}0.83 \\
0.12 \\
<\end{array}$ & $\begin{array}{l}0.20 \\
0.10 \\
001\end{array}$ & $<10$ & $<10$ & $\begin{array}{l}6.7 \\
0.8 \\
N\end{array}$ & $\begin{array}{l}8.3 \\
1.6 \\
\end{array}$ & $\begin{array}{r}9.2 \\
1.2 \\
\text { NS }\end{array}$ \\
\hline 6 & $\begin{array}{l}\text { Mean } \\
\text { SD } \\
P\end{array}$ & $\begin{array}{r}10.4 \\
0.6\end{array}$ & $\begin{array}{r}9.1 \\
0.7 \\
S\end{array}$ & $\begin{array}{r}9.9 \\
0.1 \\
S\end{array}$ & $\begin{array}{r}1.33 \\
0.15 \\
<\end{array}$ & $\begin{array}{l}0.17 \\
0.06 \\
001\end{array}$ & $\begin{array}{r}15.0 \\
4.4\end{array}$ & $\begin{array}{l}<10 \\
05\end{array}$ & $\begin{array}{r}8.0 \\
0.8 \\
N\end{array}$ & $\begin{array}{l}9.2 \\
3.2 \\
3\end{array}$ & $\begin{array}{r}9.0 \\
2.2 \\
\text { NS }\end{array}$ \\
\hline 10 & $\begin{array}{l}\text { Mean } \\
\text { SD } \\
P\end{array}$ & $\begin{array}{r}18.1 \\
2.8 \\
<\end{array}$ & $\begin{array}{r}12.1 \\
1.3\end{array}$ & $\begin{array}{r}11.1 \\
0.7\end{array}$ & $\begin{array}{r}2.03 \\
0.49 \\
<c\end{array}$ & $\begin{array}{l}0.17 \\
0.06 \\
001\end{array}$ & $\begin{array}{l}48.3 \\
11.6\end{array}$ & $\begin{array}{l}<10 \\
005\end{array}$ & $\begin{array}{r}19.0 \\
2.5 \\
<0 .\end{array}$ & $\begin{array}{l}8.6 \\
3.1 \\
01\end{array}$ & $\begin{array}{r}13.7 \\
2.3 \\
.05\end{array}$ \\
\hline 28 & $\begin{array}{l}\text { Mean } \\
\text { SD } \\
P\end{array}$ & $\begin{array}{r}76.3 \\
4.3 \\
<\end{array}$ & $\begin{array}{r}28.9 \\
2.8 \\
01\end{array}$ & $\begin{array}{r}29.7 \\
1.3 \\
S\end{array}$ & $\begin{array}{l}4.34 \\
0.30 \\
<0\end{array}$ & $\begin{array}{l}0.40 \\
0.10 \\
001\end{array}$ & $\begin{array}{r}72.2 \\
7.8 \\
\end{array}$ & $\begin{array}{l}<10-15.1 \\
001\end{array}$ & $\begin{array}{c}20.8 \\
3.5 \\
<0 .\end{array}$ & $\begin{array}{l}1.4 \\
0.9 \\
01\end{array}$ & $\begin{array}{r}5.6 \\
0.6 \\
.001\end{array}$ \\
\hline
\end{tabular}

Results are given in terms of mean $\pm \mathrm{SD}$ for each group containing three to four pups. $P$ values derived from $t$ tests compare the $\mathrm{N}$ and $\mathrm{H}$, and the $\mathrm{H}$ and $\mathrm{H}+\mathrm{T} 3$ groups at each age. $\mathrm{N}$, normal controls. $\mathrm{H}$, hypothyroid pups prepared by feeding low iodide and propylthiouracil-containing diet to pregnant mothers and throughout the period of the study. $H+T 3$, hypothyroid pups given 50 $\mu \mathrm{g} \mathrm{T} 3 / 100 \mathrm{~g}$ body weight s.c. $24 \mathrm{~h}$ before the termination of each study period.

* Serum T3 concentration was $>1,000 \mathrm{ng} / \mathrm{dl}$ in all $\mathrm{H}+\mathrm{T} 3$ rats. Concentrations of $\mathrm{T} 3<10 \mathrm{ng} / \mathrm{dl}$ were assigned a value of 9 $\mathrm{ng} / \mathrm{dl}$ in the calculation of significance. Serum T3 values in $28-\mathrm{d}$ hypothyroid pups are given as the range for the group. 


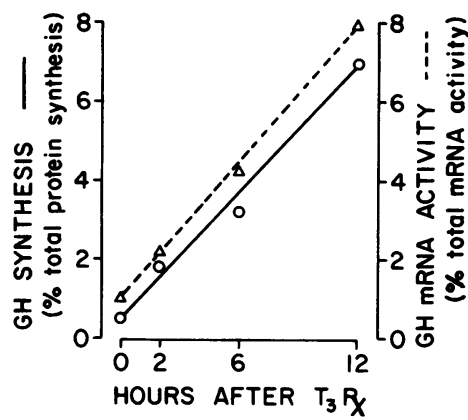

FIGURE 1 Response of GH synthesis and GH mRNA activity to $\mathrm{T} 3$ in pituitaries of adult hypothyroid rats. Hypothyroidism was induced 3 mo before the execution of the experiment. A single intraperitoneal dose of T3 ( $50 \mu \mathrm{g} / 100 \mathrm{~g}$ body wt) was given before the times indicated on the abscissa. Each point represents the mean values of duplicate determinations using pituitary tissue from six rats. The difference between duplicate determinations was within $20 \%$ of the mean value.

pups was $15.0 \pm 4.4 \mathrm{ng} / \mathrm{dl}$, reaching a level of $72.2 \pm 7.8$ $\mu \mathrm{g} / \mathrm{dl}$ at $28 \mathrm{~d}$. Serum T3 in hypothyroid pups remained either below $10 \mu \mathrm{g} / \mathrm{dl}$ or reached a maximal level of $15.1 \mathrm{ng} / \mathrm{dl}$. $24 \mathrm{~h}$ after the administration of T3, serum levels were $>1,000 \mathrm{ng} / \mathrm{dl}$.

The results of pituitary GH content were least expected (Table I). No significant differences were found between hypothyroid and normal pups 1,3 , and $6 \mathrm{~d}$. Furthermore, during the same period of time, no changes in the pituitary GH content were observed $24 \mathrm{~h}$ after administration of $50 \mu \mathrm{g}$ of T3/100 $\mathrm{g}$ body wt to the hypothyroid pups. A significant increase in pituitary GH content in response to $\mathrm{T} 3$ occurred in 10-d-old pups, when differences between hypothyroid and normal animals also became significant. At $28 \mathrm{~d}$, pituitary GH content in the hypothyroid rats decreased to levels approximately 3-fold lower than at birth, whereas that in normal rats increased by 48 -fold, resulting in an average 150 -fold difference between the two groups, as previously shown in adult rats (14-16).

The induction of $\mathrm{GH}$ synthesis and GH mRNA activity in response to $\mathrm{T} 3$ given to adult hypothyroid rats is shown in Fig. 1. The basal GH mRNA activity of $1.1 \%$ of the total mRNA doubled at $2 \mathrm{~h}$ after the administration of $\mathrm{T} 3$ and continued rising in a linear fashion over the period of $12 \mathrm{~h}$, reaching $8.0 \%$. GH synthesis rate increased in parallel. Of note is the good agreement between both parameters, GH synthesis expressed as percent total endogenous protein synthesis and GH mRNA as percent total translational activity in the cell-free system. GH synthesis and mRNA activity in age-matched normal controls were 35.9 and $36.8 \%$, respectively, and did not significantly change (33.1 and $34.4 \%) 12 \mathrm{~h}$ after the administration of T3. Furthermore, total protein synthesis (incorporation of $\left[{ }^{3} \mathrm{H}\right]$ leucine into TCA-precipitable material per milligram pituitary protein) and total mRNA activity (incorporation of $\left[{ }^{3} \mathrm{H}\right]$ leucine into TCAprecipitable material per microgram RNA added in the cell-free translation system) were not different in hypothyroid compared with normal rats.

Similar studies were carried out in the neonatal hypothyroid rat. GH synthesis and GH mRNA activity were measured at 4 and $12 \mathrm{~h}$ after the primary and secondary stimulation with $\mathrm{T} 3$, and in untreated hypothyroid, T3-withdrawn, and normal rats. Data are shown in Fig. 2. GH synthesis and mRNA activity in rats treated with T3 $14 \mathrm{~d}$ earlier (T3-withdrawn rats) were not different from those observed in the untreated hypothyroid rats. A significant increase in both parameters was observed at $4 \mathrm{~h}$ after the administration of T3. The response rate after secondary stimulation was 2.5 -fold more rapid than after primary stimulation, despite the fact that, before the administration of the second T3 dose, values in the T3-withdrawn rats had returned to the pretreatment level. The rate of increase in GH mRNA activity in the adult hypothyroid rat mimicked that observed after secondary T3 stimulation in the pups: an approximately threefold increase at $4 \mathrm{~h}$ and eightfold increase $12 \mathrm{~h}$ after T3 injection. No lag was observed in $\mathrm{GH}$ synthesis in relation to the cytoplasmic accumulation of GH mRNA during the primary stimulation of neonatal hypothyroid rats. As in normal adult rats, $\mathrm{GH}$ synthesis and mRNA activity in the normal 28-d-old pups were higher than the values achieved $12 \mathrm{~h}$ after T3 treatment, and represented $26.8 \%$ of the total protein synthesis and $27.1 \%$ of the total mRNA activity, respectively. Serum T3 concentrations at 4 and $12 \mathrm{~h}$ after T3 injection were both $>1,000 \mathrm{ng} / \mathrm{dl}$.

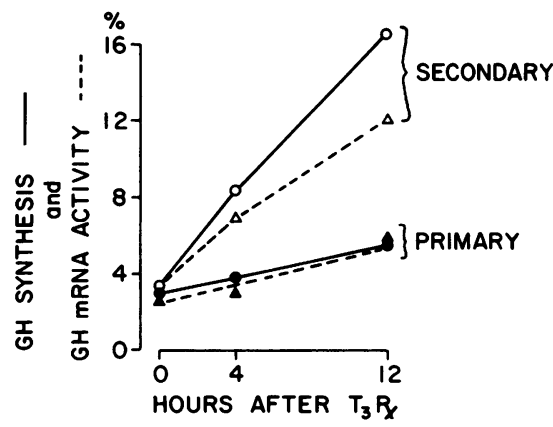

FIGURE 2 Responses of GH synthesis and GH mRNA activity to the primary and secondary stimulations with $\mathrm{T} 3$ in pituitaries of neonatal hypothyroid rats. All rats were 28 -d-old at the termination of the experiment. A single subcutaneous dose of T3 ( $50 \mu \mathrm{g} / 100 \mathrm{~g}$ body wt) was given before the times indicated on the abscissa. Secondary stimulation involved the administration of the same dose of T3 $14 \mathrm{~d}$ earlier. As in Fig. 1, pituitary GH synthesis and mRNA activity are expressed in terms of percent total protein synthesis and total mRNA activity, respectively. 


\section{DISCUSSION}

The most salient and novel findings of the present study are (a) thyroid hormone-independent accumulation of $\mathrm{GH}$ in rat pituitary during early neonatal life; (b) insensitivity of $\mathrm{GH}$ to $\mathrm{T} 3$ during the same period of neonatal life; (c) acquisition of $\mathrm{GH}$ dependence on and sensitivity to T3 between the 6th and 10th d of neonatal life; $(d)$ anamnestic response of the rate of GH mRNA accumulation with T3; and (e) absence of lag in the endogenous translation of the newly accumulated cytoplasmic GH mRNA in response to primary T3 stimulation.

The exquisite sensitivity and dependence of GH on thyroid hormone have been previously demonstrated in the adult rat and in experiments using GH-producing rat pituitary tumors in culture $(9,14-19)$. Indeed, in the hypothyroid rat, pituitary $\mathrm{GH}$ content is depressed by $90-99.9 \%(14-16)$. A 97-98\% decrease in the synthesis of $\mathrm{GH}$ has also been demonstrated in pituitaries of hypothyroid rats $(9,15)$, as well as a $76-80 \%$ diminution in $\mathrm{GH}$ accumulation in the medium of GH-producing rat pituitary cell lines deprived of thyroid hormone $(17,18)$. Previous work has also shown that GH dependence on thyroid hormone can be fully explained by the requirement of the latter to induce the transcription of the GH gene (17-19). It is thus surprising that we failed to demonstrate an effect of T3 on GH during the first $6 \mathrm{~d}$ of neonatal life in the rat. Not only was there no difference in the pituitary GH content of hypothyroid and normal pups, but $\mathrm{T} 3$ administration to the thyroid hormone-deprived pups also failed to produce a change. The latter observation indicates that the hypothyroid pup behaved as the euthyroid adult rat, in which $\mathrm{GH}$ does not respond to supraphysiologic doses of thyroid hormone $(16,20)$. Thyroid hormone appears not to be necessary for intrauterine growth and early postnatal life. Indeed, pituitary GH is unaffected by hypothyroidism, and during the same period, no significant differences in growth rate were observed between the hypothyroid and normal pups. GH dependence on thyroid hormone became manifest at $10 \mathrm{~d}$. Thyroid hormone deficiency was associated with a diminution in pituitary GH content, significant slowing in the growth rate, and appearance of $\mathrm{GH}$ response to $\mathrm{T} 3$.

The period between days 6 and 10 of the neonatal rat life, during which regulation of $\mathrm{GH}$ synthesis becomes dependent upon thyroid hormone, corresponds to the opening of the pups' eyes. In this species of mammals, normally born at a relatively immature stage of development, the time of appearance of GH dependence on T3 should correspond to the late fetal life in man. It could then be speculated that intrauterine supplementation of thyroid hormone to the athyrotic human fetus may not be necessary for normal development. Support in favor or against such a contention should become available in the future from results of early initiation of thyroid hormone replacement in the hypothyroid newborn detected by the neonatal screening programs $(21,22)$.

The rate of GH mRNA accumulation in T3-stimulated hypothyroid animals after a period of $\mathrm{T} 3$ withdrawal (secondary stimulation) was approximately 2.5-fold more rapid than after $\mathrm{T} 3$ administration to rats previously unexposed to thyroid hormone (primary stimulation). Thus, an anamnestic response to thyroid hormone, similar to that described for estrogen (1-7), has been demonstrated. The exact duration of the anamnestic response has not been defined, and it remains unknown whether it would persist throughout the entire life span of the animal. However, adult rats rendered hypothyroid responded to $\mathrm{T} 3$ with a rate of GH mRNA accumulation similar to that after secondary stimulation of neonatal hypothyroid rats $\mathrm{T} 3$ withdrawn for $14 \mathrm{~d}$. From this experiment, it appears clear that the anamnestic response persists for at least $2.5 \mathrm{mo}$, which constituted the duration between establishment of hypothyroidism and T3 stimulation of the adult rats. On the other hand, we failed to show a lag in the endogenous translation of the newly accumulated pituitary GH mRNA during primary T3 stimulation. Synthesis of GH appeared to proceed in a congruous fashion with the accumulation of cytoplasmic $\mathrm{GH}$ mRNA. In this respect, it has been shown that the presence or absence of synthesis lag varied not only with the hormone used but also according to the responding substance, the animals species, and, unfortunately, the laboratory. A lag in the endogenous translation of newly accumulated rat pituitary PRL mRNA (1) and frog liver vitellogenin mRNA (8) has been demonstrated during the primary stimulation with estrogen. The same hormone failed to show a lag in the endogenous translation of newly accumulated ovalbumin mRNA in the oviduct (2) and vitellogenin in the liver of chickens (7) and Xenopus (6). Speculations concerning possible mechanisms responsible for the manifestations of the anamnestic response appear elsewhere $(1-8,23)$. These include irreversible differentiation and/or proliferation of specialized cells capable of specific response to hormonal stimulation, permanent alterations of the chromatin in hormoneprimed cells, and rapid stabilization of the message during secondary stimulation.

\section{ACKNOWLEDGMENTS}

The authors are grateful to the National Institute of Arthritis, Metabolism, and Digestive Diseases for the provision of purified GH for immunization and as a standard, and to Dr. Leslie J. DeGroot for the review of this manuscript. The technical assistance of Mr. Swen R. Hagen and Mrs. Sheryl 
H. Allen and the secretarial help of Mrs. Yolanda W. Richmond are also acknowledged.

This work was supported in part by U. S. Public Health Service grant AM 15,070.

\section{REFERENCES}

1. Seo, H., S. Refetoff, G. Vassart, and H. Brocas. 1979. Comparison of primary and secondary stimulation of male rats by estradiol in terms of prolactin synthesis and mRNA accumulation in the pituitary. Proc. Natl. Acad. Sci. U. S. A. 76: 824-828.

2. Palmiter, R. D. 1972. Regulation of protein synthesis in chick oviduct. I. Independent regulation of ovalbumin, conalbumin, ovomucoid, and lysozyme induction. $J$. Biol. Chem. 247: 6450-6495.

3. Chan, L., A. R. Means, and B. W. O'Malley. 1973. Rates of induction of specific translatable messenger RNAs for ovalbumin and avidin by steroid hormones. Proc. Natl. Acad. Sci. U. S. A. 70: 1870-1874.

4. Baker, H. J., and D. J. Shapiro, 1977. Kinetics of estrogen induction of Xenopus laevii vitellogenin messenger RNA as measured by hybridization to complementary DNA. J. Biol. Chem. 252: 8428-8434.

5. Deeley, R. G., D. S. Udell, A. T. H. Burns, J. I. Gordon, and R. F. Goldberger. 1977. Kinetics of avian vitellogenin messenger RNA induction: comparison between primary and secondary response to estrogen. J. Biol. Chem. 252: 7913-7915.

6. Ryffel, G. V., W. Wahli, and R. Weber. 1977. Quantitation of vitellogenin messenger RNA in the liver of male Xenopus toads during primary and secondary stimulation by estrogen. Cell. 11: 213-221.

7. Jost, J. P., T. Ohno, S. Ranyim, and A. R. Schuerch. 1978. Appearance of vitellogenin mRNA sequences and rate of vitellogenin synthesis in chicken liver following primary and secondary stimulation by $17 \beta$ estradiol. Eur. J. Biochem. 84: 355-361.

8. Farmer, S. R., E. C. Henshaw, M. V. Berridge, and J. R. Tata. 1976. Translation of Xenopus vitellogenin mRNA during primary and secondary induction. Nature (Lond.). 273: 401-403.

9. Seo, H., S. Refetoff, E. Martino, G. Vassart, and H. Brocas. 1979. The differential stimulatory effect of thyroid hormone on growth hormone synthesis and estrogen on prolactin synthesis due to accumulation of specific messenger ribonucleic acid. Endocrinology. 104: 10831090.

10. Pelham, H. R. B., and R. J. Jackson. 1976. An efficient, mRNA dependent translation system from reticulocyte lysates. Eur. J. Biochem. 67: 247-256.
11. Robin, N. I., S. R. Hagen, F. Collaco, S. Refetoff, and H. A. Selenkow. 1971. Serum tests for measurement of thyroid function. Hormones (Basel). 2: 266-279.

12. Fang, V. S., and S. Refetoff. 1974. Radioimmunoassay for serum triiodothyronine: evaluation of simple techniques to control interference from binding proteins. Clin. Chem. 20: 1150-1154.

13. Birge, C. A., G. T. Peake, I. K. Mariz, and W. H. Daughaday. 1967. Radioimmunoassayable growth hormone in the rat pituitary gland: effects of age, sex, and hormonal state. Endocrinology. 81: 195-204.

14. Peake, G. T., C. A. Birge, and W. H. Daughaday. 1973. Alteration of radioimmunoassayable growth hormone and prolactin during hypothyroidism. Endocrinology. 92: 487-493.

15. Wilkins, J. N., S. E. Mayer, and W. P. Vanderlaan. 1974. The effects of hypothyroidism and 2,4-dinitrophenol on growth hormone synthesis. Endocrinology. 95: 12591267.

16. Hervas, F., G. Morreale de Escobar, and F. Escobar del Rey. 1975. Rapid effects of single dose of L-thyroxine and triiodothyronine on growth hormone as measured by radioimmunoassay. Endocrinology. 97: 91-101.

17. Seo, H., G. Vassart, H. Brocas, and S. Refetoff. 1977. Triiodothyronine stimulates specifically growth hormone mRNA in rat pituitary tumor cells. Proc. Natl. Acad. Sci. U. S. A. 74: 2054-2058.

18. Shapiro, L. E., H. H. Samuels, and B. M. Yaffe. 1978. Thyroid and glucocorticoid hormones synergistically control growth hormone mRNA in cultured $\mathrm{GH}_{1}$ cells. Proc. Natl. Acad. Sci. U. S. A. 75: 45-49.

19. Martial, J. A., J. D. Baxter, H. M. Goodman, and P. H. Seeburg. 1977. Regulation of growth hormone messenger RNA by thyroid and glucocorticoid hormones. Proc. Natl. Acad. Sci. U. S. A. 74: 1816-1820.

20. Coulombe, P., H. L. Schwartz, and J. H. Oppenheimer. 1978. Relationship between the accumulation of pituitary growth hormone and nuclear occupancy by triiodothyronine in the rat. J. Clin. Invest. 62: 1020-1028.

21. Dussault, J. H., P. Coulombe, and C. Laberge. 1975. Neonatal thyroid screening. In Perinatal Thyroid Physiology and Disease. D. A. Fisher and G. N. Burrow, editors. Raven Press, New York. 221-229.

22. Fisher, D. A., G. N. Burrow, J. H. Dussault, D. R. Hollingsworth, P. R. Larsen, E. B. Man, and P. G. Walfish. 1976. Recommendations for screening programs for congenital hypothyroidism. J. Pediatr. 89: 692-694.

23. Palmiter, R. D., and N. H. Carey. 1974. Rapid inactivation of ovalbumin messenger RNA after acute withdrawal of estrogen. Proc. Natl. Acad. Sci. U. S. A. 71: 2357-2361. 